\title{
Followership: An Important Partner of Leadership
}

\author{
Chen Tsun Yung \\ Dreeben School of Education, University of the Incarnate Word \\ 4301 Broadway, San Antonio, Texas 78209, United States \\ E-mail: tschen@student.uiwtx.edu \\ Kuan Chen Tsai (Corresponding author) \\ Dreeben School of Education, University of the Incarnate Word \\ 4301 Broadway, San Antonio, Texas 78209, United States \\ E-mail: ktsai@student.uiwtx.edu
}

Received: August 26, 2013 Accepted: September 3, 2013 Published: September 4, 2013

doi:10.5296/bmh.v1i2.4233ＵRL: http://dx.doi.org/10.5296/bmh.v1i2.4233

\begin{abstract}
Followership is the mirror image of leadership. After all, an underlying truth is that leaders would be nonexistent without the support of their followers. To some extent, the relationship between leaders and followers resembles a miniature democracy. Thus, followership should be credited as leadership. The purpose of this article was to review related literature concerning followership and to draw attention to this area because it is argued that good followership serves as an important resource for organizational development. First, the definition of followership is reviewed. Next, the qualities of good followers are examined. Then a path to effective followership is suggested.
\end{abstract}

Keywords: Followership, leadership, organizational behavior 


\section{Introduction}

It is believed three key elements are important to leaders: charisma, personality, and competence (Bateman, 2011). For followers, however, integrity and leadership values seem more important (Bateman, 2011). Indeed, distrust and discontent may trigger a disaster if followers have negative leadership experiences (Greyvenstein \& Cilliers, 2012). Thus, to some extent, followership is the mirror image of leadership.

Many scholars and practitioners of leadership support the idea of interplay between leaders and followers. Kleiner (2008) noted, "leadership and followership are two sides of the same coin, each intimately connected with the other in a dynamic manner” (p. 93). Buchanan (2007) stated, "Without great followers, leaders would become schizophrenics sitting in their offices talking to themselves" (p. 110). Attridge (1949) went further and argued that "good followership is more vital to a democracy than excessive leadership” (p. 12). Bennis (2008) had a similar thought and suggested "great followership is harder than leadership. It has more dangers and fewer rewards” (p. xxvi). Bennis (2008) also predicted that "a decade from now, the terms leader and follower will seem as dated bell bottoms and Nehru jackets" (p. xxvi). Furthermore, Cox, Plagenes, and Sylla (2010) believed that a dynamic relationship between leaders and followers reveals a possibility of interchangeable roles of leaders and followers. In other words, in some situations, "the role of follower can therefore be seen as holding within it potential for both accessing and taking on leadership functions" (Hollander, 1992, p. 71). Because of this intimate relationship between leaders and followers, Bjugstad, Thach, Thompson, and Morris (2006) proposed a bigger framework of integrating followership and leadership that is expected to maximize organizational goals and effectiveness.

The purpose of this article was to review related literature concerning followership and to draw attention to this area because it is argued that good followership serves as an important resource for organizational development. First, the definition of followership is reviewed. Next, the qualities of good followers are examined. Then a path to effective followership is suggested.

\section{Understanding Followership}

The leader-follower relationship has been investigated from different approaches, involving evolutionary theory (van Vugt, 2006), technology (Hall \& Densten, 2002), group performance (Kelly, Zrroff, Leybman, \& Martin, 2011), community nursing (Kean, Haycock-Stuart, Baggaley, \& Carson, 2011), and an African rthnic group (Hotep, 2010). Kean et al. (2011) identified two approaches on how to examine followership in the literature: individual attributes of followers and a context where followers perform effective followership. They urged more research should focus on the dynamic social construction of followership.

Rost (2008) has tried to untangle the concept between followers and followership. Generally speaking, the former is viewed as "the people who follow" (p. 54) and the latter is "the process people use to follow” (p. 54). However, Rost (2008) argued that this kind of perspective of followership, in fact, stems from the industrial view of leadership that 
dichotomizes two separate processes, which in turn results in no interactions between leadership and followership. In the end, this might lead to underestimate or, even worse, disdain the importance of followership in today's society. In order to avoid this issue, Rost (2008) defined followership as “collaborative leadership [that] is an influence relationship among leaders and collaborators who intend significant changes that reflect their mutual interests” (p. 57).

Cox et al. (2010) defined followership as a "priori choice (self-conscious) of the individual in the context of his or her relationship to the nominal leader. Issues of authority and rank play little or no role in such a choice. Followership is interactive" (p. 48). Indeed, "good followership is underpinned by human factor science” (Whitlock, 2013, p. 22). According to Whitlock (2013), the crux of followership is appropriate skills and behaviors for optimized performance, which contributes to upholding organizational development. Hence, followership is defined by Maroosis (2008) as a "discipline of competences and response-abilities" (p. 18), and he further explained that "response-ability is readiness" (p. 18). In this sense, Maroosis (2008) contended that good followership can be learned, and the most important function followers possess is to provide feedback.

Following, however, is not that clear cut. As Kean et al. (2011) wrote, "following is a complex process which was based on followers' socially co-constructed views of leaders” (p. 515). It is clear that if followers resist following, the function of leadership might break down. Because of the intercorrelation of leaders and followers, Jerry (2013) asserted that "the followers must be willing and able to be inspired and be led” (p. 348). He believed that followership is "a form of leadership" (p. 348) since followers need to "adopt some characteristics of leadership" (p. 348). The key is rooted in shared values and indispensable conditions of leaders and followers who work together to create an effective institution. In a sense, this "collective responsibility” (Jerry, 2013, p. 351) requires both parties to play a reciprocal role to achieve the same goal.

\section{Qualities of Good Followers}

Frisina (2005) pointed out that in our current culture, follower has a passive and a blind connotation. However, from the perspective of effective followership, the role of followers should be viewed as positive because it reflects that followers actively engage in the work and provide critical and constructive feedback for leaders in order to make informed decisions. In fact, a number of scholars have argued that good leaders and followers share similar characteristics (Brown, 2003; Hollander, 1992; Latour \& Rast, 2004). After all, this relationship is a two-way street. Latour and Rast (2004) noted that this connection in fact implies two dimensions of followership: competency and relationship. The former involves working effectively with others, embracing change, understanding what is expected, and seeing one's self as a resource. The latter pertains to building trust, communicating courageously, identifying with the leader, and adopting the leader's vision.

From the perspective of individuals' role orientations, Howell and Mendez (2008) proposed that there are three active roles of followership: interactive, independent, and shifting. They believed these three roles contribute to the effectiveness or ineffectiveness of the 
leader-follower relationship. The key idea is that followers are expected to enact various types of jobs and might substitute or neutralize leadership (e.g., self-management). More specifically, in today's rapid technological advances and globalization, these ever-changing environments sometimes cannot permit the traditional function of leaders to process the tasks. A follower with an independent role might be forced to take the active role to embrace an ambiguous situation in order to operate the task.

According to Lundin and Lancaster (1990), effective followers are individuals who (a) possess of a high level of organizational understanding, (b) make sound decisions, (c) show enthusiasm when asked to do tasks, (d) demonstrate strong commitment to their work, and (e) take on a high level of responsibility. Nolan and Harty (1984) suggested intelligence, cooperativeness, diplomacy, and sociability are also important qualities of good followership. As key resources for any organization, Barrette (2010) also provided seven traits of good followers: humanity, loyalty, honesty, integrity, reliability, utility, and synergy. Without a doubt, followers play an important building block to the organizational structure.

Townsend and Gebhardt (2003) further differentiated between two types of followership: active and passive. The biggest difference is the empowerment of the decision-making process. Active followership grants more power and involvement to assist leaders to form the final decisions, whereas passive followership just obeys the orders passed by leaders. It is clear that active followership will contribute more benefits because of the collecting resources of brain tanks. Along with the idea of active and passive attitudes, Kelley (1988) ranked five followership patterns from sheep, to yes-people, to alienated followers, to survivors, to effective followers. Kelley (2008) further argued that understanding these five basic followership styles is important for leaders because it reflects both positive and negative behaviors of followers. However, he admitted that there is still a long way to go to understand followership more fully.

Echoing the notion of attitudes and behaviors of followership, Chaleff (2008) proposed that there are four types of followers: implementers, resources, partners, and individualists. Followers who are implementers are high support and low challenge, and they can effectively execute the tasks but rarely to challenge the norm. Followers who are resources are low support and low challenge, and they only do enough to retain their positions. Followers who are partners are high support and high challenge, and they have more responsibilities. The last type of followers is individualists who are low support and high challenge, and their behaviors are more like maverick having fresh ideas but they are reluctant to collaborate with others. Within this framework, Chaleff (2008) believed that followers' behaviors are related to leader behaviors, and this connection retains some level of variations in the follower styles depending on the leadership styles. According to Chaleff (2008), a good follower should take risks and be courageous to take moral action when needed. In this spirit, "followers take their own responsibility seriously, in which . . . they are committed to caring for and supporting leaders who use their power for the common good, will reject budding tyrants . . . before they amass power” (p. 86).

Together, it is also suggested two important characteristics of good followers that link to 
organizational development. It can further be discussed from two categories: intrapersonal and interpersonal factors. In the intrapersonal domain, a good follower has higher emotional intelligence with an ability to understand and use their intelligences as tools for organizational development. Good followers also have higher interpersonal connections, which are not only maintained by face-to-face situation, but also need to leverage all different sources to help to improve the quality of their work. Together, these two characteristics of good followers will lead to that their work, conscience, and relationships with others and organizations are all one.

\section{A Path to Effective Followership}

Martin (2008) affirmed that in an organizational setting, the imperative role of followers is to help leaders make informed decisions. He listed ten rules of good followership: (a) do not blame your boss for an unpopular decision or policy; (b) fight with your boss if necessary; (c) make the decision and run it past the boss; (d) accept responsibility whenever it is offered; (e) tell the truth and do not quibble; (f) do your homework; (g) know the weaknesses as well as the strengths while plans are being implemented; (h) keep your boss informed; (i) if you see a problem, fix it; and (j) put it more than an honest day's work (p. 9). As a follower, it is not only to execute the tasks, but also to provide feedbacks to help leaders make proper decisions. After all, a follower is the person who knows the real situation and performs the assignments. Thus, it is important to empower followers to evaluate the process and make proper adjustments to fit the current situation, thereby executing better performance.

According to the idea of workforce performance, Blackshear (2004) suggested that a dynamic followership performance consists of five stages: employee, committed follower, engaged follower, effective follower, and exemplary follower. As this model suggests, followers turn from outsiders into insiders in an organization. The more they are engaged in the daily life of the organization, the more responsibility and important tasks they have. Their body, mind, and soul are completely integrated into the system of the organization. One survey study (Blanchard, Welbourne, Gilmore, \& Bullock, 2009) indicated that two attributes of followership, critical thinking and active engagement, are associated with work outcomes. Most important, active engagement is positively associated with job satisfaction and organizational commitment, while independent critical thinking is negatively related to organizational commitment and job satisfaction.

Under the umbrella of effective followers proposed by Kelley (1988), Jaussi, Stefanovich, and Devlin (2008) called for followership for creativity. They proposed that there are four types of effective followers for creativity and innovation in organizations: creative catalysts, creative supporters, creative statics, and creative skeptics. Their framework is similar to that proposed by Chaleff's (2008) four types of followers. The biggest difference is integrating the element of creativity into the followership attribute. These followers are different in their problem solving propensities, thinking styles, and preferences for structure. Having different styles has its strengths and weaknesses. Thus, Jaussi et al. (2008) provided several recommendations and encouraged followers to value and enhance creativity in order to facilitate innovation throughout the organization. 
Apart from an organizational level, Hertig (2010) provided several suggestions for practitioners to follow in order to become an effective follower. First, redefine followership and leadership. Second, maximize one's strengths and improve one's weaknesses. Third, engage in continuous performance evaluations and provide honest feedback. Fourth, seek opportunities. Fifth, find a mentor. Sixth, always ask why. And finally always present solutions to problems (p. 1431). Moreover, Whitlock (2013) held a positive view for applying good followership and stated that potential effects of good followership "could make a significant contribution towards establishing high performing, safety-conscious organizational teams with the will and conditions for continuous quality improvement” (p. 23).

After a survey of related literature, it is proposed that there are three key elements to being an effective follower in organizational environments. The first is work-related knowledge, especially creative and critical thinking skills. The major role of a follower is to assist a leader to make informed decisions. Thus, in the process of decision-making, creative thinking is needed to confront unambiguous and uncertain situations. In an organizational environment, ill-defined problems and urgent situations are quite common. In order to generate possible solutions to tackle the issues, followers need to use their creativity to come up with alternatives. After possible solutions emerge, followers also need to evaluate them and make judicious decisions. Here, critical thinking becomes a necessary skill to make a judgment. It is believed that followers equipped with both creative and critical thinking skills will make a significant contribution to the organization.

The second key element is good communication skills. Even though followers have great ideas and vision, they still need to present to leaders to sell their ideas. Therefore, good communication between followers and leaders is necessary to reach the shared goal. And the key to having good communication skills is to be honest and have a positive attitude. Followers need to show their concerns and interests for the common good.

The third key element to effective followership is motivation. It is clear that without strong motivation, people cannot effectively operate the tasks. A number of studies have demonstrated the importance of intrinsic motivation for workers to commit to their jobs and in turn uplift the organizational development (Amabile, Conti, Coon, Lazenby, \& Herron, 1996; Oldham \& Cummings, 1996). Motivation is the driving force that pushes individuals toward excellence. Therefore, good followers should have higher motivation to perform the required tasks and to successfully get the job done while providing high quality work in order to meet or exceed the organization's expectations.

\section{Final Remarks}

Followership should be credited as leadership. As Rosenau (2004) pointed out, "leadership requires a voluntary followership" (p. 15). Therefore, more attention, recognition, and possible investment should be given to follower development either in an organizational or educational level (Dixon \& Westbrook, 2003; Neal, 2010). Courageous followership should be embraced in our culture, especially in the milieu of a cult of leadership. Followership would then be viewed as a possible balanced power that neutralizes the consequences of toxic 
leadership in organizational life.

Throughout history, numerous events have portrayed how heroic followers overturn tyrants and how this honorable rebellion reflects the authentic voice of humanity. After all, an underlying truth is that leaders would be nonexistent without the support of their followers. To some extent, the relationship between leaders and followers resembles a miniature democracy. It is a leader's responsibility to elicit candid feedback from followers; thus, any followers who are treated as mavericks or troublemakers should not be punished. Leaders should have a positive attitude toward these followers since they play an important function of speaking the truth. Together, as Maroosis (2008) noted, "leadership and followership is about doing the right things. They are about saying the right words and hearing them in the right ways" (p. 21).

\section{References}

Amabile, T. M., Conti, R., Coon, H., Lazenby, J., \& Herron, M. (1996). Assessing the work environment for creativity. Academy of Management Journal, 39(5), 1154-1184. http://dx.doi.org/10.2307/256995

Attridge, R. (1949). Children need training in "followership"; but most educators prefer leadership. Saturday Evening Post, 221(6), 12.

Barrette, E. (2010). Balancing powers: Leadership and followership in community. Communities, 148(1), 30-33.

Bateman, T. S. (2011). Beyond charisma: What followers really need from their leaders. $T+D$, 65(6), 70-72.

Bennis, W. (2008). Introduction. In R. E. Riggio, I. Chaleff, \& J. Lipman-Blumen (Eds.), The art of followership (pp. xxiii-xxvii). San Francisco, CA: Jossey-Bass.

Bjugstad, K., Thach, E., Thompson, K. J., \& Morris, A. (2006). A fresh look at followership: A model for matching followership and leadership styles. Journal of Behavioral \& Applied Management, 7(3), 304-319.

Blackshear, P. B. (2004). The followership continuum: A model for increasing organizational productivity. The Innovation Journal, 9(1), 1-14.

Blanchard, L., Welbourne, J., Gilmore, D., \& Bullock, A. (2009). Followership styles and employee attachment to the organization. Psychologist-Manager Journal, 12(2), 111-131. http://dx.doi.org/10.1080/10887150902888718

Brown, A. (2003). The new followership: A challenge for the leaders. The Futurist, 37(2), 68.

Buchanan, E. (2007). Can there be leadership without followership? Fire Engineering, 160(8), 105-110.

Chaleff, I. (2008). Creating new ways of following. In R. E. Riggio, I. Chaleff, \& J. Lipman-Blumen (Eds.), The art of followership (pp. 67-87). San Francisco, CA: Jossey-Bass. 
Cox, R., Plagens, G. K., \& Sylla, K. (2010). The leadership-followership dynamic: Making the choice to follow. International Journal of Interdisciplinary Social Sciences, 5(8), 37-51.

Dixon, G., \& Westbrook, J. (2003). Followers revealed. Engineering Management Journal, 15(1), 19-25.

Frisina, M. E. (2005). Learn to lead by following. Nursing Management, 36(3), 12. http://dx.doi.org/10.1097/00006247-200503000-00004

Greyvenstein, H., \& Cilliers, F. (2012). Followership’s experiences of organizational leadership: A systems psychodynamic perspective. South African Journal of Industrial Psychology, 38(2), 1-10.

Hall, P., \& Densten, I. L. (2002). Following successfully: Followership and technology adoption. Prometheus, 20(2), 87-105. http://dx.doi.org/10.1080/08109020210137484

Hertig, J. (2010). Followership: Nontraditional leadership roles for new practitioners. American Journal of Health-System Pharmacy, 67(17), 1412-1413. http://dx.doi.org/10.2146/ajhp090535

Hollander, E. P. (1992). The essential interdependence of leadership and followership. Current Direction in Psychological Science (Wiley-Blackwell), 1(2), 71-75. http://dx.doi.org/10.1111/1467-8721.ep11509752

Hotep, U. (2010). African centered leadership-followership: Foundational principles, precepts, and essential practices. The Journal of Pan African Studies, 3(6), 11-26.

Howell, J. P., \& Mendez, M. J. (2008). Three perspecties on followership. In R. E. Riggio, I. Chaleff, \& J. Lipman-Blumen (Eds.), The art of followership (pp. 25-39). San Francisco, CA: Jossey-Bass.

Jaussi, K. S., Stefanovich, A., \& Devlin, P. G. (2008). Effective followership for creativity and innovation. In R. E. Riggio, I. Chaleff, \& J. Lipman-Blumen (Eds.), The art of followership (pp. 291-307). San Francisco, CA: Jossey-Bass.

Jerry, R. H. (2013). Leadership and followership. University of Toledo Law Review, 43(2), 345-354.

Kean, S., Haycock-Stuart, E., Baggaley, S., \& Carson, M. (2011). Followers and the co-construction of leadership. Journal of Nursing Management, 19(1), 507-516. http://dx.doi.org/10.1111/j.1365-2834.2011.01227.x

Kelley, R. E. (1988). In praise of followers. Harvard Business Review, 66(6), 142-148.

Kelley, R. E. (2008). Rethinking followership. In R. E. Riggio, I. Chaleff, \& J. Lipman-Blumen (Eds.), The art of followership (pp. 5-15). San Francisco, CA: Jossey-Bass.

Kelly, A. C., Zrroff, D. C., Leybman, M. J., \& Martin, A. (2011). Leaders’ and followers’ social rank styles interact to predict group performance. Social Behavior \& Personality: An International Journal, 39(7), 963-977. http://dx.doi.org/10.2224/sbp.2011.39.7.963 


\section{IIMacrothink}

Business and Management Horizons

ISSN 2326-0297

2013, Vol. 1, No. 2

Kleiner, K. (2008). Rethinking leadership and followership: A student's perspective. In R. E. Riggio, I. Chaleff, \& J. Lipman-Blumen (Eds.), The art of followership (pp. 89-93). San Francisco, CA: Jossey-Bass.

Latour, S. M., Rast, V. J. (2004). Dynamic followership. Air \& Space Power Journal, 18(4), 102-110.

Lundin, S. C., \& Lancaster, L. C. (1990). Beyond leadership: The importance of followership. Futurist, 24(3), 18-22.

Maroosis, J. (2008). Leadership: A partnership in reciprocal following. In R. E. Riggio, I. Chaleff, \& J. Lipman-Blumen (Eds.), The art of followership (pp. 17-24). San Francisco, CA: Jossey-Bass.

Martin, R. (2008). Followership: The natural complement to leadership. FBI Law Enforcement Bulletin, 77(7), 8-11.

Neal, B. (2010). Heroes and sidekicks: Ensuring proper followership. T+ D, 64(9), 76-77.

Nolan, J. S., \& Harty, H. F. (1984). Followership greater than or equal to leadership. Education, 104(3), 311-312.

Oldham, G. R., \& Cummings, A. (1996). Employee creativity: Personal and contextual factors at work. Academy of Management Journal, 39(3), 607-634. http://dx.doi.org/10.2307/256657

Rosenau, J. (2004). Followership and discretion. Harvard International Review, 26(3), 14-17.

Rost, J. (2008). Followership: An outmoded concept. In R. E. Riggio, I. Chaleff, \& J. Lipman-Blumen (Eds.), The art of followership (pp. 53-64). San Francisco, CA: Jossey-Bass.

Townsend, P. L., \& Gebhardt, J. E. (2003). The leadership-followership continuum. Leaders to Leaders, 29(1), 18-21. http://dx.doi.org/10.1002/ltl.33

van Vugt, M. (2006). Evolutionary origins of leadership and followership. Personality \& Social Psychology Review, 10(4), 354-371. http://dx.doi.org/10.1207/s15327957pspr1004_5

Whitlock, J. (2013). The value of active followership. Nursing Management, 20(2), 20-23. http://dx.doi.org/10.7748/nm2013.05.20.2.20.e677

\section{Copyright Disclaimer}

Copyright reserved by the author(s).

This article is an open-access article distributed under the terms and conditions of the Creative Commons Attribution license (http://creativecommons.org/licenses/by/3.0/). 